\title{
Cultural cooperation between Russia and Japan
}

\section{Cooperación cultural entre Rusia y Japón}

\author{
Rafik. R. Magdeev \\ Kazan Federal University, Russia \\ ORCID: https://orcid.org/0000-0002-2216-0051 \\ Alina A. Khaliullina \\ Kazan Federal University, Russia \\ ORCID: https://orcid.org/0000-0003-1018-0634
}

\section{* Correspondence}

Email: rafik.r.magdeev@gmail.com

\section{Citation:}

Rafik. R. Magdeev, Alina A. Khaliullina. Cultural cooperation between Russia and Japan. Propósitos y Representaciones, 9(SPE2), e1001. doi http://dx.doi.org/10.20511/pyr2021.v9nSPE2.1001 


\section{Summary}

It is necessary to conduct an analysis of relations between Japan and Russia to determine the main trends and prospects for joint development. The purpose of the article is to study and disclose the stages of development of cultural relations between Russia and Japan and determine its features, highlight the most pressing problems of relations and identify possible ways to build strong interstate relations. The methodological basis of the study is the analytical method, for a comprehensive analysis of the changes that occurred during the development of cultural relations between Japan and Russia. Also a prerequisite is compliance with the principles of historicism and objectivity. In the course of studying used the method of study and systematization of literature. As a result of studying the problem, we can evaluate the historical development of cultural relations between Russia and Japan. Assess the state of relations between Russia and Japan and uncover limitations and growth points to strengthen relations between Japan and Russia. The results of this study can be useful as Japanologists and to specialists dealing with the problems of Asia-Pacific as a whole.

Keywords: Sociology, History, International Studies, Russian-Japanese relations, cultural relations, Politics.

\section{Resumen}

Es necesario realizar un análisis de las relaciones entre Japón y Rusia para determinar las principales tendencias y perspectivas de desarrollo conjunto. El propósito del artículo es estudiar y divulgar las etapas de desarrollo de las relaciones culturales entre Rusia y Japón y determinar sus características, resaltar los problemas de relaciones más urgentes e identificar posibles formas de construir relaciones interestatales sólidas. La base metodológica del estudio es el método analítico, para un análisis integral de los cambios ocurridos durante el desarrollo de las relaciones culturales entre Japón y Rusia. También es un requisito previo el cumplimiento de los principios de historicismo y objetividad. En el curso de sus estudios se utilizó el método de estudio y sistematización de la literatura. Como resultado del estudio del problema, podemos evaluar el desarrollo histórico de las relaciones culturales entre Rusia y Japón. Evaluar el estado de las relaciones entre Rusia y Japón y descubrir limitaciones y puntos de crecimiento para fortalecer las relaciones entre Japón y Rusia. Los resultados de este estudio pueden ser útiles como japonólogos y para especialistas que se ocupan de los problemas de Asia-Pacífico en su conjunto.

Palabras clave: sociología, historia, estudios internacionales, relaciones ruso-japonesas, relaciones culturales, política.

\section{Introduction}

One of the best ways to improve relations between countries is to develop cultural ties. Cultural cooperation between Japan and Russia has a rich history, given that Russia continues to carry all the experience of relations since the Soviet Union. The development of cultural relations between our countries allows us to hope that all this cultural baggage will allow us to bring positive dynamics to relations between Japan and Russia as a whole. Despite the fact that the younger generation of Japanese is less and less interested in fiction, but this does not affect the popularity of fiction from Russia, so the works of Tolstoy and Dostoevsky are one of the most beloved, especially for middle-aged and older Japanese people. Good examples in this direction are the fabulous popularity of the "Brothers Karamazov" published in Japan, which has a circulation of over 640,000 copies, thereby becoming the most popular work from foreign literature. We can say that Russian literature is a favorite for the Japanese, such a success of Russian literature is not an exception, but rather a regularity.

The interest in Japanese culture is mutual, it's enough to recall how well the Japanese intellectuals perceived the Japanese theater in 1920, despite the fact that the Japanese theater toured Russia for the first time, but for our compatriots this was a real sensation, the originality of the Japanese style was amazing. Interest in the theater is mutual, so when the Mariinsky or the 
Bolshoi is on tour in Japan, the auditoriums in Japan are always crowded. The halls are full when touring circus performances. Another example is the popularity of A. Kurosawa's films in the 1960s, although Kurosawa was significantly influenced by Russian filmmakers, including Andrei Tarkovsky himself. Although in Japan they love Mikhalkov's films, and there are many fans of Tarkovsky's works. Another important example already in 2010 is the considerable popularity of Japanese classical literature, including the famous Japanese haiku poems, many works have been translated into Russian, with the support of Hyperion Publishing House. Considering other aspects of Japanese and Chinese culture, tea ceremonies and ikebana should be noted ${ }^{1}$. In Russia, they are particularly interested in the art of Bonsai, as well as in the game of Go. The interest in the culture of the countries of the neighbors is mutual, so the Japanese have special love for the musical works of Shostakovich and Tchaikovsky. Not to mention classical literature, one cannot but note how they admire the performing skills of pianist Richter, bass Chaliapin, cellist Rostropovich and violinist Oistrakh. But the Japanese are familiar not only with classical literature, but also well aware of Russian songs from "Katyusha", "Troika", "Dark Eyes" to "Dubinushka". For the Japanese, the melody and mood of Russian songs is extremely attractive, sometimes it happens that the Japanese even know Russian songs better than Russian. If we consider such an aspect of culture as sport, it should be noted that in Russia there was a very high interest in Judo (Japanese wrestling), and then interest in the form of martial arts "Karate" increased. In Russia, as well as around the world, now anime is popular - Japanese animation. You need to understand that Japanese anime differs from Western cartoons, so the audience of anime, unlike cartoons, is not limited to children, and is also designed for an adult audience. Fans of anime and cosplay (a form of embodiment of the action performed on the screen) hold their own events and festivals. Also, Japanese music is very popular among Russian youth. Most often, teenagers listen to such directions as J-Rock (Japanese rock music) and J-Pop (Japanese pop music). Many Japanese groups have already visited Russia.

\section{Methods}

Cultural relations are an important factor in normalizing relations and requires a separate study. If we talk about the current time, cultural ties are developing dynamically, promotes mutual understanding of countries and helps to create a more detailed image of a partner and neighbor. But at the same time, a number of problems continue to exist between our countries, the solution of which is necessary for the development of cooperation and the realization of the potential of neighboring countries. Studying all these issues will make it possible to identify trends and possible plans and development options for the relationship between Japan and Russia.

The aim of the work is to disclose the stages of development of cultural relations between Russia and Japan in the post-Soviet period and determine its features, highlight the most pressing problems of relations and identify possible ways to build strong interstate relations.

To achieve these goals, the following tasks are solved:

To study the conceptual approaches to the concept of foreign policy, to define the concept of cultural relations, to analyze the legal framework of cultural cooperation between Russia and Japan;

To analyze the historical development of cultural relations between Russia and Japan; Identify constraints and growth points to strengthen relations between Japan and Russia;

To determine the current state of relations between Russia and Japan and to reveal the prospects for the development of relations.

\footnotetext{
${ }^{1}$ Alikberova A.A., Muhametzianov R.R. Humanitarian communication in the system of russianchinese relations: results of research work / A.A.Alikberova, R.R.Muhametzianov // The Turkish Online Journal of Design, Art and Communication - TOJDAC November 2016 Special Edition - P. 2358-2363
} 
The methodological basis of the study is the analytical method, for a comprehensive analysis of the changes that occurred during the development of cultural relations between Japan and Russia. Also a prerequisite is compliance with the principles of historicism and objectivity. In the course of studying the issue, a method of studying and systematizing the literature was used.

The theoretical basis was the work of associate professor Komsomolsky-on-Amur State Technical University Kiba Daria Vladimirovna, James Baxter and university professor Hiroshima Julia Mikhailov.

The degree of knowledge of this topic according to a preliminary review of the literature shows that in the post-Soviet period relations between the countries did not develop so dynamically, the territorial claims of Japan, or as the problem of the "northern territories" is also called, was a complicating factor. But at the same time, cultural exchange made a huge contribution to the normalization of relations between our countries. Cultural relations is an important factor in normalizing relations.

\section{Results}

Cultural relations between our countries has rich experience. So in the Soviet period, cultural relations between the countries were legally based on the "Agreement on Cultural Relations" of May 31, 1986, therefore it is not surprising that the first stage of Japanese-Russian relations in the field of culture was connected with the search for legal grounds for cooperation (Kiba, 2012). One of these documents was the "Agreement on Cultural Relations", which was signed in September 2000 , during the visit of the President of Russia to Japan. This agreement entered into force in 2002 and marked the beginning of the second stage of development of cultural relations between Japan and Russia. The agreement contained the principles of exchanges not only in the field of culture in all its diversity, but also in areas such as tourism development, youth exchanges, etc. But cultural cooperation was not limited to this agreement, the governments of the countries also cooperated at the level of joint projects carried out both by public structures and at the government level, the Moscow Declaration on Establishing a Creative Partnership between the Russian Federation and Japan, 1998, played its role in this she stated that, "The countries, recognizing the importance of promoting the mutual enrichment of the cultures of the peoples of Russia and Japan, intend to continue to encourage the various ties between the two countries in domain of culture" (Ageeva, 2013).

One of the most important documents that are the legal basis for cultural cooperation between Japan and Russia is the "Russian-Japanese Action Plan", which was signed in 2003. According to this document, the parties agreed to increase cultural and educational exchanges and youth exchanges, deepen bilateral relations, develop work in the following areas: organize joint seminars and forums between institutions and research organizations, familiarize themselves with each other's traditions and cultural values. This document covered many areas of activity within the framework of bilateral relations, ranging from the economy to the humanitarian sphere (Russian-Japanese action plan, 2003).

The second stage in the development of cultural relations between Russia and Japan is rich in the number of events and meetings. Against this background, the work of non-governmental institutions is particularly interesting, since they implemented cultural projects much faster, unlike government cultural projects. Japan went further in the matter of holding cultural events in Russia, with the support of non-governmental organizations and local governments held events introducing Japanese culture.

The result of joint work was the organization and holding of the event "Festival of Japanese Culture" in Russia, this festival was held from April 2003 to March 2004. A similar event, the Festival of Russian Culture, was held in Japan in 2006 (Vladimir Putin sent a message to the organizers and participants of the "Festival of Japanese Culture in Russia 2003). The government of both countries noted the incredible effectiveness of cultural projects, in which the state establishes a structural framework and provides information support, Nomura Issei, who at 
that time held the post of Ambassador Extraordinary and Plenipotentiary of Japan to the Russian Federation, also noted this. Particularly effective was the work of the Japanese Foundation nongovernmental organization. This organization was created in 1972, but the government's investment is the financial foundation of the organization (Russia-Japan Relations: New Stage of Development, 2019). In Russia, the activities of this organization are well known due to incredible efforts in the direction of representing Japanese culture. In Japan, there is a similar organization from Russia called the Japan Center, which is also funded by the government. In addition to the Japan Fund, a number of Japanese centers operate in Russia, in cities such as Moscow, Khabarovsk, Vladivostok, St. Petersburg and Nizhny Novgorod. The activity of these centers is aimed at close cooperation with the regions in the field of culture, and also serves as a basis for education and training of specialists.

An example of regional cooperation is the signing of a memorandum of understanding on cooperation in the fields of economy, culture and education, signed by the Governor of Miyagi Prefecture Yoshihiro Murai and the Governor of the Nizhny Novgorod Region Valery Shantsev.

It should be noted the work of another non-profit organization in Japan, called the "Friendship Society of Japan and Russia", it was created as part of the Youth Chamber of the Liberal Democratic Party of Japan. The main activity of this organization was to hold meetings with Russian government agencies. But similar organizations working in Russia since 2008, the decree of the President of Russia was created "The Federal Agency for CIS Affairs, Compatriots Living Abroad and International Humanitarian Cooperation", the organization is the successor to "ROSZARUBEZHTSENTR"(Kiba, 2012). This agency unites over 70 public organizations within the framework of the Russian Association for International Cooperation (RAMS). One of the key organizations that make up this association is the Russia and Japan Society, which was created in 1991 (Kiba, 2012). This company participates in publishing and translation activities, receives representatives of scientific and cultural circles of Japan, and establishes private contacts with individual citizens of the two countries. So thanks to this organization, the artist Miyamoto Tsutomu in the Far East, established on his own initiative creative links with the museums of Amursk, Komsomolsk-on-Amur, Nikolaevsk-on-Amur, Vladivostok and Khabarovsk. This artist organized exhibitions of works by artists of Komsomolsk-on-Amur in Yokohama, organized an exchange of drawings by children of Japan and Russia.

The governments of Russia and Japan are well aware of the importance of the opinions of people who shape public opinion, such as: scientists, journalists, artists and young people. Therefore, the governments of both countries support youth exchange programs (Mikhailova \& William, 2008).

Considering the current relations between Russia and Japan, it should be noted that, recently, Russian-Japanese relations have been strengthening more than ever, the number of contacts between the leaders of our countries has also increased significantly (Gaiko no kansuru yoron tesa, 2018). This has become possible, among other things, due to the fruitful work of the leaders of our countries. One of the key events contributing to the development of relations was the signing of a joint action plan aimed at developing relations between Russia and Japan in January 2003 during a meeting between the Russian president and the Japanese prime minister (Russian-Japanese action plan, 2003). This document contains a wide range of specific actions in the bilateral relations and such directions that will enhance cooperation between the two countries in international, including global problems.

The Japanese government also adopted a program to provide more than $\$ 6$ billion in economic assistance to Russia to support Russian reforms. The interest of peoples is also growing significantly in the field of culture, for example, throughout Russia over 2003, more than 130 events were held as part of the "Festival of Japanese Culture in Russia-2003", also a similar event was held in Japan in 2006 under the name "Festival of Russian Culture in Japan" (Baxter, 2009).

On the whole, one cannot fail to single out a series of events reflecting the current state of relations between Russia and Japan, since on July 7, 2007, Japanese Prime Minister Abe and 
Russian President Putin held a summit in Heiligendamm. In the time of the meeting the leaders confirmed their intention to cooperate in accordance with the "Japan-Russia Action Plan", including the territorial issue for a limited time. Prime Minister Morimoto announced that the Japanese-Russian joint film "Nina on the Battlefield" is under development, and now this pleasure as a joint Russian-Japanese-Russian project is being implemented. The cooperation has confirmed that he is doing a good job of this, which also contributes well to mutual understanding between the Russian and Japanese peoples (http://kremlin.ru).

One of the key events of 2013 was the visit of Prime Minister Abe to Russia on April 29, speaking together with the President of Russia during the Russian-Japanese summit, a joint statement was announced on the development of the Russian partnership and nine documents, including an agreement on the creation of a cultural center (Volkov, 2015). According to the results of the meeting, it was said, "From the point of view of cultural and human exchange of views, an agreement was reached on the importance of expanding the base of bilateral relations and deepening mutual understanding by improving human exchange". One of the interesting meetings in terms of cultural relations between Russia and Japan was on October 7, 2013, when Prime Minister Abe said: "Exchange of people is one of the important keys to developing relations between Japan and Russia that they want to expand exchanges with a focus on young generations, and now they will study in Japan, these are about 300 foreign students from Russia, about 100 Japanese students studying in Russia, and that they want to increase this figure by five times by 2020 , respectively. In addition, in order to increase the incentive to study abroad, I would like to support cooperation, including the compatibility of divisions and the degree of acquisition of Russia and Russia, saying that I would like to cooperate with each other using the opportunities" (Yennie-Lindgren, 2018).

One cannot but mention the official visit to Japan by the President of the Russian Federation V.V. Putin from 15 to 16 December 2016, which took place in the cities of Tokyo and Nagato, for the bilateral relations it was a breakthrough. This trip was incredibly effective, as more than 68 commercial documents were signed as a result of the meeting, as well as 12 interdepartmental and intergovernmental documents. During President Putin's visit to Japan, Japan announced the easing of visa requirements for Russian citizens (Russia-Japan Relations: New Stage of Development, 2015). In response to the April 27-28, the Prime Minister of Japan visited Russia, following the results of the meeting, the results of joint work, the level of implementation, agreements reached were summed up, and further steps were agreed to improve and develop relations between Russia and Japan. Leaders met again "on the margins" summit "Group of Twenty" in Hamburg on July 7. The Prime Minister of Japan confirmed his intention to participate in the next Eastern Economic Forum in Vladivostok in September (Sevastyanov, 2017).

In the future, contacts at a high level began to grow. So, Foreign Minister Sergey Lavrov and Japanese colleague F. Kishida held talks in Tokyo in April 2016, then they met again in Moscow in December of the same year. on February 17 in Bonn, within the event "a group of twenty" next year, our Foreign Minister had a meeting again. Efforts are being made to develop Russian-Japanese cooperation in practical areas (Panov, 2016). The Minister of Economy, Trade and Industry of Japan, as well as on the development of economic cooperation with Russia, $\mathrm{H}$. Seko, visited Moscow on January 11-12, where he was received by First Deputy Prime Minister I.I. Shuvalov, Minister of Energy A.V. Novak and Minister of Industry and Trade D.V. Manturov (Minister of Economy, 2020).

On January 11-12, 2017, an advisory council was created to promote Japanese-Russian interregional and inter-parliamentary cooperation following the meeting of the "Discussion club". The delegation of deputies led by K.I. Kosachev took part in the second meeting, the second meeting was held in Tokyo from June 8 to 10, 2017. On Jule 17, 2017 Deputy Chairman of the Japan-Russia "Discussion Club" M. Matsuyama with Valentina Matvienko met in Moscow. And in December 2017, according to the results of the meeting, it was announced that 2018 will be the cross-year of Russian culture in Japan and the year of Japanese culture in Russia. Cultural exchange plays an extremely important role in promoting bilateral relations between Russia and Japan. So in June, Russia has launched a global cultural project "Russian Seasons". Tokyo was the 
first city, and Japan was the first country where an event of this level was held, this indicates the level of relations that exists between our countries. "Russian Seasons" is a global project focused on the promotion and acquaintance with Russian culture with all the achievements in this direction, in all its glory. Such an event is major therefore takes place throughout the year, and the territorial coverage is more than 40 cities (Russia-Japan Relations: New Stage of Development, 2019).

On the occasion of the launch of the "Russian Seasons" in Japan, Tokyo Deputy Chairman of the Government of the Russian Federation O.Yu. Golodets visited Tokyo from 3 to 6 June, she had a brief conversation with Prime Minister S. Abe, who was present at the ceremony.

On July 7, the opening of the annual Festival of Russian Culture in Japan took place, attended by First Deputy Prime Minister I.I. Shuvalov (Shuvalov, 2020).

At the level of deputy foreign ministers of Russia and Japan, negotiations are underway regarding the conclusion of a peace treaty. These negotiations are not the first time, as far as we know, such meetings were held in October 2015, in Japan such a meeting was held on June 22, 2016, and then in Moscow on August 26, 2016. The positions of the parties are quite clear, Russia seeks to recognize the outcome of World War II by Japan, and only if this issue is recognized, can negotiations be promoted, Japan, for its part, seeks to return the "Northern territories".

Nevertheless, negotiations between our countries are ongoing and there is some progress on this issue, as a statement was agreed on joint economic activities in the southern Kuril Islands, for residents of Japan simplifying travel procedures to the southern Kuril Islands to visit the graves of their ancestors. This mission is implemented in several stages, so stage 1 was associated with the organization of a meeting in Yuzhno-Sakhalinsk of a private-state mission to discuss the possibilities of joint economic activity, stage 2 was held in the southern Kuril Islands from June 27 to July 1 (Russia-Japan Relations: New Stage of Development, 2019).

In Japan, it was the first time organized a large-scale cultural project "Russian Seasons" in 2017. The opening ceremony was attended by Japanese Prime Minister Shinzo Abe and Deputy Prime Minister of the Russian Federation O. Yu. Golodets (Zhuravsky, 2020).

Due to the fact that in December 2016, an agreement was reached at the highest level to hold in 2018 one of the largest events, the "Festival of Japanese Culture in Russia-2018" is held in Russia and the "Festival of Russian Culture in Japan-2018", which accordingly will be held in Japan. Within the framework of these projects, various events were planned in the areas of cultural and humanitarian cooperation, scientific, technical, interregional economic, information and communication, as well as in the field of politics. The opening took place on June 12, 2018 (Richardson, 2010).

If we talk about the current period of time, it should be said that now is a favorable period for building relations between Japan and Russia at the same time, one cannot proceed from high expectations, so as not to be disappointed, but to act consistently and cold-bloodedly. Continue to negotiate, to hold meetings in all possible levels. At the moment, there is only one difficult problem between our countries - this is a territorial issue, but even it can be resolved with joint and consistent work with an appropriate level of trust and partnership.

From this moment and it becomes clear how important cultural ties and humanitarian cooperation between Russia and Japan. Cultural relations contribute to increasing mutual interest of countries to each other, but for these purposes it is necessary to expand cultural exchanges between young people, cultural figures, entrepreneurs, scientists, journalists, representatives of certain regions of the country.

We must strive to ensure that the political dialogue between the countries is trustful and continues to develop, we know from history that an attempt to put pressure on partners and linkages is extremely ineffective and does not contribute to solving problems. Therefore, the 
strategy of our countries seems to be the only true one, as the systematic active development of bilateral relations, the interaction of countries on key issues, and the implementation of contacts between the general population of our vast homeland will contribute to the solution of such complex problems, and contributes to stability between countries.

From all of the above, we can conclude that the current state of relations between Russia and Japan shows positive dynamics, but it is not necessary to prematurely loudly declare the solution of geopolitical problems between the countries, since this is not correct and premature, but it can be stated with confidence that the strategy chosen between our countries the most faithful. Relations between our countries are systematically developing from year to year, the number of contacts at various levels is becoming more frequent, mutual understanding between countries is coming, but it is important for us not to ruin this level of achievement, and to prevent the destruction of the agreements reached in the state of embryo. Building relations between Japan and Russia is impossible without a sufficient level of perseverance, and mutual steps must be taken towards meeting the interests of each of the parties.

\section{Discussion and Conclusion}

From the foregoing, we can conclude that despite the existence of a territorial dispute between our countries, cultural relations between Russia and Japan are developing dynamically, projects are becoming more efficient and scaled. Cultural relations are the very means of promoting mutual understanding between countries. So between our countries several stages of the development of cultural relations took place, the first stage took place from 1991 to 2002 in the framework of the "Agreement on Cultural Relations of May 31, 1986" (Ageeva, 2013), the second stage began in 2003 and continues to this day under the "Agreement on cultural ties" which was signed in September 2000. The legal framework of bilateral relations and the contractual framework is of great importance and contributes to the implementation of cultural ties at all levels. Cultural relations between Russia and Japan can also be useful experiences in culture relations with China (Rafisovna Alikberova, 2016). The vigorous activity of public circles to comprehend the traditions and cultures of each other helps to create a positive image of a partner, increase the level of mutual understanding of countries and strengthen interstate relations between Russia and Japan.

\section{Acknowledgements}

The work is performed according to the Russian Government Program of Competitive Growth of Kazan Federal University.

\section{References}

Ageeva, A.A. (2013). Establishing the interstate relations of Russia and Japan at the end of the 17th and mid-19th centuries: Bulletin of the Pskov State University. Series: Social sciences and humanities "History and Archeology, 38-55.

Alikberova, A.A., \& Muhametzianov, R.R. (2016). Brief Terminological Analysis of the RussianChinese Humanitarian Cooperation. International Journal of Humanities and Cultural Studies, 112-117.

Alikberova, A.A., \& Muhametzianov, R.R. (2016). Humanitarian communication in the system of Russian-Chinese relations: results of research work. The Turkish Online Journal of Design, Art and Communication - TOJDAC November 2016 Special Edition, 2358-2363.

Baxter, J.C. (2009). Interpretations of Japanese culture: views from Russia and Japan. Kyōto-shi : Kokusai Nihon Bunka Kenkyū Sentā, 87-102.

Beginning of conversation with Japanese Prime Minister Shinzo Abe chronology June 7, (2007). Available at: http://kremlin.ru/events/president/transcripts $/ 24320$ (date accessed 07.04.2020)

Gaiko no kansuru yoron tesa 2018. Tesa kekka no gayyo [Public Opinion Poll. A summary of its results. 2018]. Office of the Cabinet of Ministers of Japan. Available at: https://www.survey.gov-online.go.jp/h30/h30-gaiko/2-1.html (date accessed 01.04.2020) 
Japan-Russia Action Plan. kremlin.ru. Available at: http://www.kremlin.ru/supplement/4684 (date accessed 05.04.2020)

Kiba, D.V. (2012). Cultural relations between Russia and Japan in the post-soviet era. Sovremennye issledovania socialnyh problem, 10(18), 2-10.

Mikhailova, Y. (2014). Japan and Russia constructing identity - imagi(ni)ng the other. Evgeny Steiner No longer magical but even more attractive - Japan's changing image in the imagination of Russian. St. Petersburg Centre for Oriental Studies Publishers St. Petersburg, 171-190.

Mikhailova, Y., \& William M. (2008). Steele Japan and Russia Three centuries of mutual images. Tsuneo Akaha, Anna Vassilieva. Images in Tinted Mirrors: Japanese-Russian Perceptions in Provincial Japan, 153-174.

Minister of Economy, Trade and Industry of Japan to visit Russia on January 11-12, Available at: https://tass.ru/ekonomika/3924287 (date accessed 09.04.2020)

Panov, A. (2016). Japan-Russia relations implications for the U.S.-Japan alliance. A View from Russia on Japan-Russia Relations in the mid-2010s: Searching for a Framework to Move Forward, 31-40.

Richardson, W. (2010). Russian relations with Japan from 2000-2010: enduring obstacles, limited opportunities, Northeastern University Boston, Massachusetts, 144-458

Russia-Japan Relations: New Stage of Development. (2019). Working Paper. Russian International Affairs Council (RIAC). -Moscow: NPMP RIAC, 50, 7-38.

Russian-Japanese action plan. (2003). Yearbook. Moscow: Publishing house "MAKS-Press", 336353.

Sevastyanov, S. (2017). Hopes and Realities in Relations Between Russia and Japan: Is a Breakthrough Possible?. Springer Science+Business Media Dordrecht, 34, 39-62.

Shuvalov opened the festival of Russian culture in Japan, Available at: https://rg.ru/2017/07/07/shuvalov-otkryl-festival-rossijskoj-kultury-v-iaponii.html (date accessed 11.04.2020)

Vladimir Putin sent a message to the organizers and participants of the "Festival of Japanese Culture in Russia 2003", which opens on April 20, 2003 in St. Petersburg, Available at: http://kremlin.ru/events/president/news/28508 (date accessed 01.04.2020)

Volkov, S.V. (2015). Japan in the Russia - U.S. Relations. MGIMO Review of International Relations, 1(40), 35-42.

Yennie-Lindgren, W. (2018). New dynamics in Japan-Russia energy relations 2011-2017. Journal of Eurasian Studies, 9, 152-162.

Zhuravsky, A. (2020). "Russian Seasons" in Japan form a field of understanding of two nations, Available at: https://tass.ru/interviews/4291193 (date accessed 09.04.2020) 